\title{
Retreat to Orthodoxy Diminishes Democratic Negotiations
}

\author{
Patrick Bishop \\ Department of Politics, Philosophy and Religion, Lancaster University \\ and \\ Center for Public Administration and Policy, Virginia Tech
}

\begin{abstract}
A REVIEW ARTICLE:
Nancy Bermeo and Jonas Pontusson (eds.) Coping With CRISIS: Government REACTIONS to THE GREAT RECESSION, RUSSELL SAGE FOUNDATION, NEW YORK, 2012

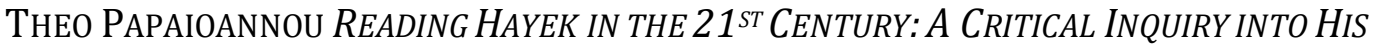

Political Thought Palgrave Macmillan, Basingstoke, 2012

This review essay enters into the contested waters of the connections between theory and practice. The first volume explores the recent economic crisis and various government's responses to it without making any direct reference to the theorist at the heart of the second volume, Friedrich von Hayek. A look at these two works in tandem seems a good opportunity to explore John Maynard Keynes' view that:
\end{abstract}

the ideas of economists and political philosophers, both when they are right and when they are wrong, are more powerful than is commonly understood. Indeed the world is ruled by little else. Practical men, who believe themselves to be quite exempt from any intellectual influence, are usually the slaves of some defunct economist. Madmen in authority, who hear voices in the air, are distilling their frenzy from some academic scribbler of a few years back. I am sure that the power of vested interests is vastly exaggerated compared with the gradual encroachment of ideas. (Keynes, JM 1936: 383) 
If Keynes was right there should be much to be gained by looking at the Great Recession of 2008 through the two lenses of economic policy responses and political theory.

As I start to write this, on 1 August 2013, the Dow Jones Index is at a record high level $(15,650)$. As you read this, am I confident that we can say that the crisis of the Great Recession has been "coped with?" Although this classic indicator is looking healthy, I am no less confident than authors Nancy Bermeo and Jonas Pontusson were in February 2012, with the Dow at 12,977, nearly double the low of March 2, 2009 of 6,626 , when they wrote... " it is quite clear that the negative consequences of the great recession are still being felt. Stock prices have not reached their prerecession level in Britain or the United States."(p.28). We can now see the index soon passed its pre-recession high of Oct $12007(13,930)$. In fact, the upward trajectory has only been checked when the continuation of the Federal Reserve's quantitative easing has been questioned ${ }^{1}$. Whatever else is at work here it is clear that the actions or even rumored actions of a central bank are having a dramatic effect on the Index. The clear message being sent from the market is that government stimulus and quantitative easing (the expansion of the money supply) should remain in place. Is Hayek's paradox, explored below, the reason why his thought can be seen by some as the cause and by others as the apparent cure for the Global Recession?

Along with the author of the second work, Theo Papaioannou, I would argue that Hayek's "academic scribbling" is still influential on the policy responses to the Great Recession outlined here. Further, I agree that any logical flaws or inconsistencies in his theoretical work should be of concern to those developing the policy responses to economic crises. For Papaioannou, reading Hayek will, among other things, allow us to "understand that the public policy attempts towards developing spontaneous

${ }^{1}$ Decisions taking in the US also have a bearing on other markets and their indices fluctuate accordingly. Interestingly, even as the later debt ceiling crisis loomed the stock market remained buoyant. 
orders of the last 30 years have contributed to the $21^{\text {st }}$ century turmoil of advanced industrial capitalism." (p.181) I would contend, and maybe the exclusion of his name from the policy survey backs this up, that the strength of this orthodoxy has come about through not reading Hayek. What we have seen is a much more organic gradual encroachment of an idea about the distribution of public goods and services and about justice. I remember speaking to one of the architects of the Australian version of New Public Management and he admitted, despite being an economist, he had "never read Hayek". The precise mechanisms whereby such ideas gain currency are a matter worthy of further study, but as we see from Papaioannou's thorough and careful study to expose the "immanent critique" in Hayek's political thought reveals a worrying paradox leading to logical flaws in any policy prescriptions it might direct.

The paradox at the heart of Papaioannou's reading is that Hayek's political thought both "excludes and requires substantive politics," a point that he makes several times in the book. From a philosophical and logical point of view this kind of paradox renders Hayek's political thought suspect. That Hayek, along with others, is seen as one of the authors of the current market orthodoxy is surely disturbing. Even more disturbing is that the strength of that orthodoxy in the policy community has not been shaken. In the survey of the range of policy responses to the global financial crisis of 2008 in Bermeo and Pontusson's book, without any mention of Hayek by name, there is no policy position adopted in response to the crisis that ultimately challenges this orthodoxy even in the event of catastrophic market failure.

Bermeo and Pontusson have collected together an interesting selection of cases to explore the causes and policy responses to what they term "the Great Recession". The book covers a good range of topics from the more theoretical chapters with an international focus: "Modern Capitalism and the Advanced Nation State: Understanding the Causes of the Crisis" from Torben Iversen and David Soskice and the offering from Eric Helleiner on "Multilateralism" to chapters that offer comparisons from Europe; between France and Germany; Ireland and Southern 
Europe; A stand alone chapter on the US response from Nolan McCarty; a comparison of Nordic countries; Japan; Great Britain and (again) Ireland. It is perhaps unfair to point to any omissions as such an enterprise cannot cover everything. Although the editor's Introduction begins with a reference to the Chinese ideograph for crisis (p.1) there is no chapter on China. Granted China protected it self from the crisis but it too as a major actor in the global economy also had to "cope" with the global crisis. It might also have been helpful if there had been something on the two economies within the liberal democratic capitalist camp that went into the recession in relatively strong economic positions, Canada and Australia. The reasons why I am not yet sanguine about the future of global capitalism in the 21st century is also at the very point where the two texts in review here intersect.

In the intersection of theory and practice ideology plays an important role. Doctrinaire ideological positions, while the 'stuff' of political theory, can be particularly damaging to good or appropriate policy outcomes and to the necessary pluralism of ideas in a well functioning democracy (and, incidentally, a well functioning market). And this can be either on the right or left; no matter what the circumstances there should never be an increase in taxation; no matter what the circumstances state ownership of the means of production is desirable. For example, the American's for Tax Reform (ATR) pledge, signed by a significant number of Republican Party legislators in the US, to "oppose any and all efforts to increase the marginal income tax rate for individuals and business; and to oppose any net reduction or elimination of deductions and credits, unless matched dollar for dollar by further reducing tax rates." (http://www.atr.org/taxpayer-protection-pledge) As Nolan McCarty's chapter (pp.201-233) shows this doctrinaire approach to policy leads to predictable outcomes in terms of policy response among representatives in Congress. Congress in this doctrinaire mode ceases to be site for democratic deliberation and negotiation. The line from Ben Bernanke that just as there a no atheists in foxholes there are "no ideologues in financial crises" (p.202) does not seem to be borne out in practice of the US legislature, as the chapter shows, a 
representatives ideological preference seems to be a remarkably stable indicator of how they are going to vote on any issue. If anything, this crisis has solidified the ideological partisanship with actors establishing themselves as committed ideologues rather than as negotiators. Negotiations "across the aisle" have been notably absent. If ever there was a time for legislators to open to different policy responses it should be in a time a crisis. The crisis is surely a sign that there is at least the possibility that there something a fault with current legislation, regulation, oversight or policy settings in general.

In the UK case the Labour government nationalized the ownership of banks, not as a Labour government might have done in earlier times in the interests of socialization, but to rescue the financial institutions from the results of their own bad practices and a failed regulatory regime. This government ownership was also only ever seen as an expedient until they are able to sold back into private hands. At no time did the Labour government see its ownership of the banks as a possible mechanism that could, for example, influence the availability of credit for struggling homeowners or to provide the credit that had all but dried up for the small business sector, a fact that the Labour government nevertheless bemoaned. Chancellor Darling is reputed to have said of these measures that he had just implemented the Labour Party's policy from 1983 - what had been called "the longest suicide note in history" - and with Conservative party support! The lack of any positive strategic intervention by the newly government-owned banks in economic recovery shows that, despite this massive intervention by government, the commitment to market orthodoxy remained strong and such comments about the ideology of 'old' Labour were only made ironically.

So for these reasons Papaioannou is right that we should be reading and rereading Hayek but I am still unsure as to precisely what he means by "substantive politics". If we change the qualifier to non-substantive or insubstantial politics what does it tell us? I believe that he is making a case that politics of the left is substantive politics in that it creates a good life through political action. I'm not sure that Hayek 
and the other free marketeers are actually saying that politics should have no substance to it. They have a clear idea of the kind of politics that is acceptable. Small government, minimum regulation and so on but that also requires a political state apparatus. What they seek is a politics in support of the free market. As we will see that politics is not necessarily free, democratic politics. So what we have, in light of the acceptance of an idea of Hayek's is a substantive politics that sets the political agenda in such a way that its version of the market prevails. But it is also not a free market, not pluralist but tending to monopoly; it is in the end an undemocratic market. As we can see in my opening paragraphs the market relishes and thrives on the substantive politics of quantitative easing, bail-outs and subsidy. Take away that stimulus, that form of substantive politics, and the market slides.

Both Canada and Australia were in stronger positions at the start of the Great Recession. However, perhaps as a reflection of globalization, both governments also implemented stimulus packages in response to the economic downturn. China continued to grow with a very tightly managed economy. Hayek's concerns in his day were directed against what he saw as a dangerous, complacent Keynesianism. I wonder what Hayek would have made of the kind of command capitalism that we see in China today?

McCarty's chapter juxtaposes pragmatism with ideology but here we need a cautionary to note that, for Keynes, it is the self-believing "practical men" who are subject to the ideas of the defunct economist. Thus without the challenge from a plurality of ideas characteristic of well functioning democratic politics the slide into orthodoxy will inevitably occur, even amongst the non-ideologues. Where Papaioannou argues that Hayek could be seen as making the free market a higher value than a continuing democracy, in fact it is democracy and pluralism that maintains the critical reflection on the facts and circumstances that can lead to helpful policy innovations rather than the orthodox acceptance of a single ideological certainty that the spontaneous order of the market is always right. 
Hayek's catallaxy, or spontaneous order, is after all, an attempt at the nonideological ideology. Spontaneity replaces the need for a grand ideological architect. The market is the invisible hand that creates order. It is irrational in that it is not the product of reason but the product of multiple actors making their own individual choices. Some critics find in this idea an inherent conservatism: the spontaneous order is justified through it's being organic; its longevity; its tradition. For Hayek the result of an order created through collective knowledge manifested by market interactions is always to be preferred to rational planning built on a grand ideological design because of the threat posed by totalitarianism, not primarily to democracy, but to the market. When this was expressed in the polarized terms of the Cold War between liberal democracy and Soviet totalitarianism, or West and East, the contrast is clear. However, when the contest is between two versions of liberalism, the issues and the problems of the paradox in Hayek's work becomes more complex. This is perhaps why in Hayek's polemic The Road to Serfdom he needs to draw his critique of planning as if a liberal democratic mixed market economy is inevitably the same thing as soviet communism.

Ideology is always a problem for what we might call broadly liberal thinkers. It is the liberal's concern to not express a version of the good life in the interests of preserving individual autonomy that leads to the kind of problem Papaioannou identifies as paradoxical in Hayek's political thought. However, when the ideology of no ideology comes to rest in the political and policy arena any subtleties are lost. Contained in the simple slogan or a mindset that sees no alternative, where political intransigence is taken as a mark ideological purity through a blind adherence to a free market ideology. That the argument begins from an apparent attempt to be non-ideological is truly ironic.

In a democratic pluralist society ideology, at best, informs politics it cannot and should not prescriptively guide the details of policy. Policy must be the result of democratic negotiation. It is also important that foundational documents and the rule of law are subject to interpretation and negotiation in light of current 
circumstances and practices. The commitments of representatives, on behalf of citizens, should be to the maintenance of the democratic process not to particular policy outcomes and regulations. A further irony is that it is a commitment to process that is at the heart of free markets, and it is in this that Hayek's illogical paradox is exposed: he is unwilling to allow for democratic government to be governed by the free market in ideas and policy that he asserts as essential for economic exchange. In short, political theory is not public policy. Political theory espoused as doctrine constrains both democratic politics and free markets.

In looking at the range of responses to the crisis in Bermeo and Pontassons's collection we see that they are all conducted under the rubric of preserving the free market. Even the Nordic countries with their stronger social democratic past return to the orthodoxy. They, along with other economies, adopt massive fiscal stimulus packages in response to the crisis. In fact they do so with, according to Johannes Lindvall's comparison between the Great Depression of the 1930s and the Great Recession of 2008, more commitment from the center- right parties than was the case of the social democrats of the 1930s. (pp. 233-260) However, Lindvall argues that the return to a more austere policies even though unemployment remains high (pp.255) indicates that, just like the UK Labour party, their apparent Keynesianism was to cope with the crisis rather then to challenge the market orthodoxy. Support, bailouts and regulation are all designed to keep the market functioning and by the measurement of the Dow Jones Index, we can observe that the single most significant factor in causing it's decline in the recovery phase is the action not of free enterprise profit or innovation but a change in the policy of the central bank to maintain the flood of money. This is not coming about from the reading or rereading of Hayek (and others) but rather from the pervasive belief in the orthodoxy: that there is no alternative. Where Papaioannou identifies a logical flaw and paradox in Hayek creates a new kind of substantive politics, one that has a conception of the good. Not the goods of social justice, equality or democracy but the good of the continuation of the market at the cost of these other goods. Papaioannou 
places this in perhaps its most sinister context of Hayek's approval of the Pinochet regime and extends this to the view of Mises from 1927 that 'It cannot be denied that Fascisms and similar movements aiming at the establishment of dictatorships are full of the best intentions and tat their intervention has, for the moment, saved European civilisation' (p.202 note 1) In the light of this shadow over the implication of some of Hayek's later comments, it should be noted that in the current crisis we have seen the emergence of a virtual technocracy in Italy with the appointment of former EU commissioner Mario Monti as Prime Minister and a jump in support as austerity measures were introduced for the proto-fascist Golden Dawn political party in Greece.

That a political theorist is paradoxical is not, of itself a crime. It may well be that the political circumstances are themselves paradoxical. However, in the realm of political and economic theory market collapse is technically possible even desirable. It is in the realm of practical politics that notions such as "too big to fail" shape government action. On the ideological left Marx of course, predicts the collapse of the capitalism. On the ideological right, some free market capitalists using Joseph Schumpeter's term "creative destruction" have also advocated the collapse of the current system. On this line of thought, true free market capitalism can only be brought about once the current over-regulated redistributive form of capitalism has failed. In some cases this has even been related to a religious apocalyptic view, in fulfillment of biblical Prophesy.

From a policy response perspective, what is clear that even in a survey of different economies we see a commonality in the responses that seems unhealthy from a point of view of democracy. Democracy should, indeed must, have a diversity of views about what should be done. The move to orthodoxy destroys the potential creativity that the democratic marketplace of ideas and policy responses across polities should produce. It is these differences that also provide the true value of the comparative methodology. Conformity of policy response also provides little grist to the comparative mill. The virtue of comparative politics is not simply as a 
methodological tool for academics but an opportunity to explore a plurality of responses that vibrant democratic policy requires.

The other important concept in looking at how governments govern is to see the role that reason and evidence plays. The political game has increasingly been played in a manner where the facts, laws, regulations are ignored. Where public institutions and office holders are subject to campaigns of misinformation; where media abrogates its responsibilities in keeping citizens informed and instead "entertains" in a manner that exacerbates partisan divisiveness. Further, a new irrationality is evident in market and media responses to the actions regulatory authorities over the past decades that, I would argue, impacts on both the crisis and the response to the crisis. There seems to be a shift in focus, away from regulations towards the personalities of the regulators. They are not classic Weberian anonymous bureaucrats. Instead their personal predilections are seen as having some kind of dominion over the economic fortunes of the nation. The recent appointment of Mark Carney as the first non-British head of the Bank of England is a good case in point. From Canada, he is seen as not only the face of the regulatory success that meant Canada did not participate in the Great Recession, it is now assumed that he can "work his regulatory magic" in the UK. His appointment was greeted in the press with a great deal of speculation and included, rather oddly, that his wife was campaigning on Twitter for a reduction in the use of tea bags for environmental reasons. The leaders of regulatory institutions are now celebrities. This was so certainly of Alan Greenspan, Ben Bernanke at the Federal Reserve and there was considerable speculation on his possible replacement in the media. The market seems to have approved of the final appointment of Janet Yellen, the other front-runner, Larry Summers, being seen as somewhat of a maverick. Such actors are not always responsible in the way they exercise this power. In Australia the currency dropped dramatically when the Reserve Bank governor speculated about an interest rate cut only to later say it was a joke! (Australian Financial Review 4 July 2013) 
The crisis has seen governments adopt previously discredited Keynesian policies as a coping strategy. But they are not entirely 'slaves' to this 'defunct economist'. Any opportunity for these policies to work on income redistribution, social inequality or even small business assistance seems to have been ignored, even in case of political parties (the UK Labour Party) or governments (Sweden and Denmark) with an historic commitment to such measures. It is a surely mark of the strength of an orthodoxy that it can survive such a clear indications of its limitations.

I am struck that three works I reference here are from the 1930 and 40s. Their three authors were coping with crisis. Our current crisis has been/ is being coped with. The coping mechanism seems to me Keynesian in character but Hayekian (and Schumpterian) in purpose. That is: governments and regulators are supporting the market but not in the interests of a redistribution of wealth but to support the expanding inequality of modern capitalism. The policy responses have all been designed to keep the market in place; to support institutions "too big to fail" that were nonetheless failing. While Keynes believed in a redistribution of wealth as a mechanism to preserve democracy, Hayek (and current policy makers, it seems) believe that the market brings democracy. Paradoxically, then, if the market is under threat democracy can be suspended or curtail.

As I finish this the US had just apparently averted, or at least postponed, what was being predicted as another Global Financial crisis, arising from the US defaulting on its debt payment. The political intransigence seen amongst Republican members of Congress concerned, not so much a reluctance to raise the debt ceiling, but the introduction of The Affordable Care Act (ACA). The attempted negotiation was that the debt ceiling would be raised only if the roll out of the ACA was postponed for I year. Both of these are an anathema to what has become known as the "Tea Party" ideology. A belief in small government, reduced taxation, less regulation are well within Hayek's free market economics and politics (although the theorist who is usually cited as the major influence is Ayn Rand.) But in these actions the Republicans in Congress showed little respect for not only democratic processes but 
also the rule of law. The Affordable Care Act, had not only been an important part of the preceding Presidential election campaign but had been subject to challenge in the High Court by a number of State governments and found by a conserva tive High Court to be constitutional. So this threatened action even contradicted the substantive politics that Hayek does endorse - the adherence to the rule of law. This potential crisis was not about a policy failure in terms of the maintenance of the global market system but driven entirely by political intransigence in the name of an ideological commitment to lower taxes and no provision of health care to the most needy in US society. Most interestingly, the market, in the form of the Dow Jones Index at least, didn't blink.

\section{Bibliography}

Hayek, Friedrich A. (1944) The Road to Serfdom, Chicago, The University of Chicago Press, Chicago IL

Keynes, John Maynard (1936) The General Theory of Employment Interest and Money Harcourt, Brace New York

Schumpeter, Joseph A. (1942) Capitalism Socialism and Democracy Harper: New York 